\title{
Effectiveness of Localized Basal Expansion Technique vs Chest Manipulation Technique on Improving Respiratory Status among Patients with Lower Respiratory Tract Disorders at MGMCRI, Puducherry: A Comparative Study
}

\author{
Ariraman Praimathi ${ }^{1}$, Surendran Raju ${ }^{2}, \mathrm{~K}$ Renuka ${ }^{3}$
}

\begin{abstract}
Background: Oxygen is very much important for the human body. Oxygen plays a vital role in breathing processes and in the metabolism of the living organism. The primary purpose of respiratory system is gas exchange which involves the transfer of oxygen and carbon dioxide that are passively exchanged by a diffusion process between the gaseous external environment and the blood. The exchange processes occurs in the alveolar region of the lungs. The respiratory system enables to produce energy by supplying the body with a continuous oxygen supply. It is also responsible for eliminating carbon dioxide, which is an end product of cell metabolism, whereas oxygen is necessary for human respiration. Materials and methods: A quantitative research approach was used for this study. The research design used for this study is an experimental research design. This study was conducted in MGMCRI, Puducherry. The population of this study was 60 (30 local basal expansion technique and 30 chest manipulation technique) and was selected by using a simple random sampling technique (randomization with lottery method). The data were collected through a structured questionnaire consisting of part A and part B. Part A consists of sociodemographic data, and part B consists of rating scale to assess the respiratory status.

Results: Discussion on the finding was arranged based on the objective of this study. This study revealed that out of 30 samples, 23 (76.6\%) of them had poor respiratory status, 7 (23.3\%) of them had very poor respiratory status, and none of them had good respiratory status in pretest, whereas in posttest, 19 (63.3\%) of them were in good respiratory status, 11 (36.6\%) of them were in poor respiratory status, and none of them were in very poor respiratory status for the localized basal expansion technique. This finding revealed that out of 30 samples, 21 (70\%) of them had poor respiratory status, $9(30 \%)$ of them had very poor respiratory status, and none of them had good respiratory status in pretest, whereas in posttest, $26(86.6 \%)$ of them were in good respiratory status, $4(13.3 \%)$ of them were in poor respiratory status, and none of them were in very poor respiratory status for the chest manipulation technique.

Conclusion: This study implies that when compared with the localized basal expansion technique, the chest manipulation technique was effective in improving the respiratory status among patients with respiratory disorders.

Keywords: Chest manipulation technique, Localized basal expansion technique, Lower respiratory tract disorders, Respiratory status.

Pondicherry Journal of Nursing (2019): 10.5005/jp-journals-10084-12113
\end{abstract}

\section{INTRODUCTION}

Breathing is important for two reasons, the primary function is to supply oxygen to our body cells which is vital for our survival. ${ }^{1}$ It is essential for the integrity of the brains, nerves, glands, and internal organs. ${ }^{2-4}$ We can do without food for weeks and without water for days, but without oxygen we will die within a few minutes, if the brain does not get proper supply of this essential nutrient, it will result in the degradation of all vital organs in the body. The second function of breathing is to remove the waste products and toxins from the body. ${ }^{5,6}$

The recent statistics says that almost 26 million adults over the age 40 in India had respiratory disorders, and the data monitoring expect this number to increase $34 \%$ to approximately 32 million by 2020 (Canadian Thoracic Society, 2011). ${ }^{7-9}$

Recent studies have shown that incidence of dyspnea among adults is increasing in Puducherry; $51.5 \%$ of the population is affected by respiratory disorders. ${ }^{4}$ In that, $38.7 \%$ of the adults were severely affected, and $12 \%$ of geriatric people were affected by respiratory problems (Directorate of Health and Family Welfare, 2011)..$^{10-12}$

\footnotetext{
${ }^{1-3}$ Department of Medical Surgical Nursing, Kasturba Gandhi Nursing College, Sri Balaji Vidyapeeth Deemed University, Puducherry, India

Corresponding Author: K Renuka, Department of Medical Surgical Nursing, Kasturba Gandhi Nursing College, Sri Balaji Vidyapeeth Deemed University, Puducherry, India, Phone: +91 9486537848, e-mail: renukagugan@yahoo.co.in

How to cite this article: Praimathi A, Raju S, Renuka K. Effectiveness of Localized Basal Expansion Technique vs Chest Manipulation Technique on Improving Respiratory Status among Patients with Lower Respiratory Tract Disorders at MGMCRI, Puducherry: A Comparative Study. Pon J Nurs 2019;12(2):38-41.
}

Source of support: Nil

Conflict of interest: None

There can be various disorders of this respiratory system which can be reversible or irreversible. The major disorders of the respiratory include asthma, emphysema, bronchitis, lung cancer, cystic fibrosis, pulmonary fibrosis, rhinitis, chronic obstructive pulmonary disease (COPD), bronchiectasis, tuberculosis, pneumonia, pulmonary embolism, and pulmonary hypertension. ${ }^{13}$

(0) The Author(s). 2019 Open Access This article is distributed under the terms of the Creative Commons Attribution 4.0 International License (https://creativecommons. org/licenses/by-nc/4.0/), which permits unrestricted use, distribution, and non-commercial reproduction in any medium, provided you give appropriate credit to the original author(s) and the source, provide a link to the Creative Commons license, and indicate if changes were made. The Creative Commons Public Domain Dedication waiver (http://creativecommons.org/publicdomain/zero/1.0/) applies to the data made available in this article, unless otherwise stated. 
The brain requires more oxygen than any other organ. If it does not get enough oxygen, it will result in mental sluggishness, negative thoughts and depression, and, eventually, vision and hearing decline. ${ }^{14,15}$ Old people and those whose arteries are clogged often become senile, because oxygen to the brain is reduced. ${ }^{16-18}$ The oxygen supply is reduced to all parts of the body as we get older due to poor lifestyle. Many people need reading glasses and suffer hearing decline in old age because of oxygen demand. ${ }^{19-21}$

The raising of the rate respiratory disorders among adults in worldwide is because of environmental factors and bad habits such as cigarette smoking, tobacco chewing, and alcohol consumption. ${ }^{22,23}$ The morbidity and mortality rate of increasing in the United States is 7\%, British is 6.5\%, and China is $4.23 \%$ (US Centre for Disease Control and Prevention, 2012). ${ }^{24,25}$

Greenberg et al. (2013) reported the incidence of respiratory disorders as $68 \%$ at the time of the death. Respiratory disorders can be quite prevalent in patients with congestive heart failure. ${ }^{26,27}$

According to National Heart, Lung and Blood Institute (2011), one in six deaths in adults was due to a lung disease. ${ }^{28,29}$ Chronic lower respiratory disease, which includes COPD and asthma, ranks third (behind cancer). ${ }^{30,31}$ Hypertension, asthma, coronary artery disease, and COPD are especially prevalent and account for substantial morbidity in Americans. ${ }^{32-34}$

\section{Statement of the Problem}

"A comparative study to assess the effectiveness of localized basal expansion technique vs chest manipulation technique on improving respiratory status among patients with lower respiratory tract disorders at MGMCRI, Puducherry"

\section{Objectives}

- To assess the respiratory status among patients with lower respiratory tract disorders during pretest and posttest.

- To assess the effectiveness of the localized basal expansion technique and chest manipulation technique on level of respiratory status among patients with lower respiratory disorders.

- To compare the effectiveness of the chest manipulation technique vs localized basal expansion technique among patients with respiratory disorders.

- To associate the effectiveness of the chest manipulation technique and localized basal expansion technique with the level of respiratory status among patients with lower respiratory tract disorders with their selected demographic variables.

\section{HyPOTHESES}

- H1: There will be significant difference in the level of respiratory status before and after administration of the localized basal expansion technique among patients with lower respiratory tract disorders.

- H2: There will be a significant difference in the level of respiratory status before and after administration of the chest manipulation technique among patients with lower respiratory tract disorders.

- H3: There will be a significant association between the effectiveness of the chest manipulation technique and localized basal expansion technique on improving respiratory status among patients with lower respiratory tract disorders with their selected demographic variables.

\section{Materials and Methods}

A quantitative research approach was used for this study. The research design used for this study is an experimental research design. This study was conducted in MGMCRI, Puducherry. The population of this study was 60 (30 local basal expansion technique and 30 chest manipulation technique) and was selected by using a simple random sampling technique (randomization with lottery method). The data were collected through a structured questionnaire consisting of part A and part B. Part A consists of sociodemographic data such as age, sex, religion, educational status, type of occupational status, nature of work, income, marital status, bad habits, how many years exposure of bad habits, frequency of bad habits, any previous history of respiratory disorders, and types of medication exposure, and part B by using the rating scale comprises pulse rate, respiratory rate, lung sound, oxygen saturation, capillary refilling, blood pressure, sputum, voice, weight, and chest wall expansion, and the intervention such as localized basal expansion technique and chest manipulation technique was given. The data analysis through descriptive and inferential statistics was carried out.

\section{Results}

The findings from Table 1 revealed that out of 30 samples, 23 (76.6\%) of them had poor respiratory status, 7 (23.3\%) of them had very poor respiratory status, and none of them had good respiratory status in pretest, whereas in posttest, 19 (63.3\%) of them were in good respiratory status, 11 (36.6\%) of them were in poor respiratory status, and none of them were in very poor respiratory status.

Thus, the research hypothesis is that there will be a significant difference in the range of respiratory status before and after administration of the localized basal expansion technique among patients with respiratory disorders is accepted statistically.

The findings from Table 2 revealed that out of 30 samples, 21 (70\%) of them had poor respiratory status, 9 (30\%) of them had very poor respiratory status, and none of them had good respiratory status in pretest, whereas in posttest, $26(86.6 \%)$ of them were in good respiratory status, 4 (13.3\%) of them were in poor respiratory status, and none of them were in very poor respiratory status.

Table 1: Frequency- and percentage-wise distribution on respiratory status among patients with the localized basal expansion technique $(n=30)$

\begin{tabular}{|c|c|c|c|c|c|}
\hline \multirow[b]{3}{*}{ S. no. } & \multirow[b]{3}{*}{ Level of respiratory status } & \multicolumn{4}{|c|}{ Localized basal expansion technique } \\
\hline & & \multicolumn{2}{|r|}{ Pretest } & \multicolumn{2}{|c|}{ Posttest } \\
\hline & & $n$ & Percentage & $n$ & Percentage \\
\hline 1 & Good respiratory status & - & - & 19 & 63.3 \\
\hline 2 & Poor respiratory status & 23 & 76.6 & 11 & 36.6 \\
\hline 3 & Very poor respiratory status & 07 & 23.3 & - & - \\
\hline
\end{tabular}


Table 2: Frequency- and percentage-wise distribution on level of respiratory status among patients with the chest manipulation technique $(n=30)$

\begin{tabular}{|c|c|c|c|c|c|}
\hline \multirow[b]{3}{*}{ S. no. } & \multirow[b]{3}{*}{ Level of respiratory status } & \multicolumn{4}{|c|}{ Chest manipulation technique } \\
\hline & & \multicolumn{2}{|r|}{ Pretest } & \multicolumn{2}{|c|}{ Posttest } \\
\hline & & $n$ & Percentage & $n$ & Percentage \\
\hline 1 & Good respiratory status & - & - & 26 & 86.6 \\
\hline 2 & Poor respiratory status & 21 & 70 & 04 & 13.3 \\
\hline 3 & Very poor respiratory status & 9 & 30 & - & - \\
\hline
\end{tabular}

Table 3: Comparison of respiratory status among patients with respiratory disorders of pre- and posttest for the localized basal expansion technique and chest manipulation technique

\begin{tabular}{|c|c|c|c|c|c|c|c|}
\hline \multirow[b]{2}{*}{ Technique } & \multicolumn{2}{|c|}{ Pretest } & \multicolumn{2}{|c|}{ Posttest } & \multirow[b]{2}{*}{ Mean difference } & \multirow[b]{2}{*}{ tvalue } & \multirow[b]{2}{*}{ pvalue } \\
\hline & Mean & $S D$ & Mean & $S D$ & & & \\
\hline Localized basal expansion technique & 89.94 & 01.79 & 93.74 & 01.70 & 3.80 & 13.407 & $0.05^{*}$ \\
\hline Chest manipulation technique & 90.00 & 02.14 & 96.60 & 01.61 & 6.60 & 17.545 & $0.001^{* * *}$ \\
\hline
\end{tabular}

${ }^{*} p<0.05$, significant and ${ }^{* *} p<0.001$, highly significant

Thus, the research hypothesis is that there will be a significant difference in the range of respiratory status before and after administration of the chest manipulation technique among patients with respiratory disorders is accepted statistically.

The findings from Table 3 revealed that the paired test " $t$ " value of respiratory status among respiratory disorder patients in the localized basal expansion technique is $t=13.407$ and $p<0.05$. Hence, it is significant. The paired test " $t$ " value of oxygen saturation among respiratory disorder patients in the chest manipulation technique is $t=17.54$ and $p<0.001$. Hence, it is highly significant.

\section{ReCOMmEndations}

Based on the findings of this study, the following recommendations have been made:

- Similar study can be conducted in other parts of the country with a large sample.

- The same study can be conducted in different settings.

- The same study can be conducted with true experimental research design.

- The study can be replicated with larger samples for better generalization.

- The study can be done as a longitudinal study.

- The study can be replicated with biophysical parameters.

\section{Conclusion}

This study implies that when compared with the localized basal expansion technique, the chest manipulation technique was effective in improving the respiratory status among patients with respiratory disorders. The study findings reveals that the patients consuming bronchodilators shows increased in the risk of decreased oxygen saturation range among patients with respiratory disorders. This may be due to inadequate effect of the drug over the bronchioles which will lead to improper and ineffective dilation of the narrow airway patency.

\section{References}

1. Dechman G, Wilson CR. A study on the efficiency of pursed lip breathing and diaphragmatic breathing in the rehabilitation of people with COPD; 2005;84(12):1189-1197.
2. Lewis SL, Heitkemper MM, Dirksen SR, OBrien PG, Bucher L. Medical surgical nursing 7th ed., Philadelphia: Mosby Elsevier Publications; 2006.

3. Onodera A, Yazaki K. Effects of a short-term pulmonary rehabilitation program on patients with chronic respiratory failure due to pulmonary emphysema. Nihon Kokyuki Gakkai Zasshi 1998;36(8):679-683.

4. Polaski AL, Tatro SE. Luckmann's Core Principles and Practice of Medical Surgical Nursing. 5th ed., W. B. Saunders Company; 1996.

5. Breslin EH. The pattern of chest wall muscle recruitment during pursed lip breathing. NIm Catalog 1992;101(1):75-78. DOI: 10.1378/ chest.101.1.75.

6. Rhoads CS, Yoneda KY. Chronic Obstructive Lung Disease. (Online) vol. 1, 2002; pp. 112-115.

7. Chawla K, Mukhopadhay C, Majumdar M, Bairy I. Bacteriological profile and their antibiogram from cases of acute exacerbations of chronic obstructive pulmonary disease: a hospital based study. J Clin Diagn Res 2008;2:612-616.

8. Collins EG, Langbein WE, Fehr L, Maloney C. Breathing pattern retaining and exercises training and exercise training in patients with chronic obstructive pulmonary pulmonary diseases. J Respir Med 2008;98(13):1234-1240.

9. Ignatavicius DD, Linda Workman M, Mishler MA. Medical Surgical Nursing. W.B. Saunders Company; 1995.

10. American Lung Association of Minnesota Report: COPD Hospitalizations on the Rise Across State. 2008. COPD Statistics; 2008 (online).

11. Scanlon PD, Connet JE, Waller LA, Altose MD, Bailey WC, Sonia Buist $A$, et al. A study on smoking cessation and lung function in mild-to-moderate chronic obstructive pulmonary disease. Am J Respir Crit Care Med 2000;161(2):381-390. DOI: 10.1164/ajrccm.161.2. 9901044.

12. Perry P. Basic nursing - essentials for practice. 5 th ed., St Louis: MosbyElsevier; 2003.

13. Pulmonary and critical care bulletin. Chronic obstructive lung disease (online). vol. VIII, No. 4, October 15, 2002.

14. Ritz T, Roth WT. Behavioral interventions in asthma. Breathing training. Behav Modif 2003;27(5):710-730.

15. Spahija J, Marchie M, Grassino A. Effects of imposed pursed lips breathing on respiratory mechanics and dypsnea at rest and during exercise in COPD. Chest J 2005;128(2):640-650. DOI: 10.1378/ chest.128.2.640.

16. Langer D, Ciavaglia C, Faisal A, Webb KA, Neder JA, Gosselink R, et al. Types of exercise breathing retraining and inspiratory muscle. J Physio 2007;101(2):225-232.

17. Zhang ZQ, Chen RC, Yang QK, Li P, Wang CZ, Zhang ZH, et al. The effect of pulmonary rehabilitation with respiratory physiologyzhongguo. Wei thong bingjijiu xue 2008;20(10):607. 
18. Wedzicha JC, Paul EA, Garrod R, Garnham R, Paul EA, Jones PW. Randomized controlled trial of pulmonary rehabilitation in severe chronic obstructive pulmonary disease patients, stratified with the MRC dyspnoea scale. Eur Respir J 1999;54(3):581-586. DOI: 10.1136/ thx.54.3.242.

19. Jones P, Calverley P, Larsson T. St George's Respiratory Questionnaire (SGRQ) scores may help identify COPD patients at increased risk of death over 1 year. Fifth International Multidisciplinary Conference on Chronic Obstructive Pulmonary Disease (COPD5), Birmingham, UK; 2006.

20. Bausewein C, Farquhar M, Booth S, Gysels M, Higginson IJ. Measurement of breathlessness in advanced disease: a systematic review. Respir Med 2007;101(3):3339-3410. DOI: 10.1016/ j.rmed.2006.07.003.

21. Cross J, Elender F, Barton G, Clark A, Shepstone L, Blyth A, et al. $A$ randomised controlled equivalence trial to determine the effectiveness and cost-utility of manual chest physiotherapy techniques in the management of exacerbations of chronic obstructive pulmonary disease (MATREX). Health Technol Assess 2010;14(23):1-147. DOI: 10.3310/hta14230.

22. McCool FD, Rosen MJ. Nonpharmacologic airway clearance therapies ACCP evidence-based clinical practice guidelines. Chest 2006;129(Suppl 1):250S-259S. DOI: 10.1378/chest.129.1_suppl.250S.

23. Tydeman DE, Cross JL. Respiratory physiotherapy manual techniques: review of the literature. Physiotherapy 2001;87(11):603. DOI: 10.1016/ S0031-9406(05)61134-0.

24. Fruchter O. Predictors of long-term survival in elderly patients hospitalized for acute exacerbations of chronic obstructive pulmonary disease. Respirology 2008;13(6):851-855. DOI: 10.1111/ j.1440-1843.2008.01367.

25. Bernard-Narbonne F, Daoud P, Castaing H, Rousset A. Effectiveness of chest physiotherapy in ventilated children with acute bronchiolitis [article in French]. Arch Pediatr 2003;10(12):1043-1047. DOI: 10.1016/ j.arcped.2003.09.033.
26. Greenberg-Dotan S, Reuveni H, Tal A, Oksenberg A, Cohen A, Shaya $\mathrm{FT}$, et al. Increased prevalence of obstructive lung disease in patients with obstructive sleep apnea. 2014;18(1):69-75. DOI: 10.1007/s11325013-0850-3.

27. Button BM, Heine RG, Catto-Smith AG, Phelan PD, Olinsky A. Postural drainage and gastro-oesophageal reflux in infants with cystic fibrosis. Arch Dis Child 1997;76(2):148-150. DOI: 10.1136/adc.76.2.148.

28. Nicholas KJ, Dhouieb MO, Marshall TG, Edmunds AT, Grant MB. An evaluation of chest physiotherapy in the management of acute bronchiolitis. Physiotherapy 1999;85(12):669-674. DOI: 10.1016/ S0031-9406(05)61230-8.

29. Mayordomo-Colunga J, Medina A, Rey C, Díaz JJ, Concha A, Los Arcos $\mathrm{M}$, et al. Predictive factors of non invasive ventilation failure in critically ill children: a prospective epidemiological study. Intensive Care Med 2009;35(3):527-536. DOI: 10.1007/s00134-008-1346-7.

30. Ntoumenopoulos G, Gild A, Cooper DJ. The effect of manual lung hyperinflation and postural drainage on pulmonary complications in mechanically ventilated trauma patients. Anaesth Intensive Care 1998;26(5):492-496. DOI: 10.1177/0310057X9802600503.

31. Clini EM, Antoni FD, Vitacca M, Crisafulli E, Paneroni M, Chezzi-Silva S, et al. Intrapulmonary percussive ventilation in tracheostomized patients: a randomized controlled trial. Intensive Care Med 2006;32(12):1994-2001. DOI: 10.1007/s00134-006-0427-8.

32. Magill SS, Klompas M, Balk R, Burns SM, Deutschman CS, Diekema D, et al. Developing a new, national approach to surveillance for ventilator-associated events*. Crit Care Med 2013;41(11):2467-2475. DOI: $10.1097 / C C M .0 b 013 e 3182 a 262 \mathrm{db}$.

33. Paulus F, Binnekade JM, Vroom MB, Schultz MJ. Benefits and risks of manual hyperinflation in intubated and mechanically ventilated intensive care unit patients: a systematic review. Crit Care 2012;16(4):R145. DOI: 10.1186/cc11457.

34. Kallet RH. Adjunct therapies during mechanical ventilation: airway clearance techniques, therapeutic aerosols, and gases. Respir Care 2013;58(6):1053-1073. DOI: 10.4187/respcare.02217. 